\title{
THE INFLUENCE OF THERAPEUTIC MODALITIES ON THE FUNCTIONAL ABILITY OF PATIENTS WITH RHEUMATOID ARTHRITIS
}

\author{
Nikola Krstić1, Ivana Kostić ${ }^{2}$, Ana Petronijević ${ }^{3}$, Ivana Damnjanović ${ }^{4}$
}

\begin{abstract}
Rheumatoid arthritis (RA) is a chronic, systemic inflammatory disease. The progressiveness of the disease and damage to the joints caused by RA can make a significant impact on the functioning ability. The gold standard for assessing functional status in RA is the HAQ questionnaire.

The aim of the study was to assess the impact of sociodemographic characteristics, laboratory parameters of interest and therapeutic modalities on the functional ability of patients with RA.

A retrospective cross-sectional study involved 109 patients, 29 male and 83 female, with a diagnosis of RA. Data on the demographic and clinical characteristics of the patients, laboratory findings and applied therapeutic modalities were collected. Microsoft Office Excel and PASW were used for statistical analysis. An estimation error level of less than $5 \%(0.05)$ was used as the statistical significance threshold.

The results of the study indicate that more than a third of the participants have a HAQDI greater than 1, which indicates a significant decrease in functional ability. The largest number of subjects with a high HAQ-DI index (41.2\%) was observed in the group of subjects who used glucocorticoids in combination with several synthetic disease-modifying drugs (GC + multiDMARD). The values of HAQ-DI differ statistically significantly in relation to the applied therapeutic modalities $(p=0.004)$. HAQ-DI significantly correlated with the values of sedimentation rate $(p<0.05)$, CRP $(p<0.01)$ and anti-CCP $(p<0.05)$. PLUM regression analysis showed that functional ability was impaired in the group of subjects without and with a smaller number of comorbidities. In addition, the results of regression analysis indicate that the therapeutic modalities GC + methotrexate $(p=0.023)$ and $G C+$ multiDMARD $(p=0.002)$ can significantly contribute to better functional ability in patients with RA.

Methotrexate, alone or in combination with other drugs, can significantly contribute to better functional ability and is effective in the treatment of most patients with RA.
\end{abstract}

Acta Medica Medianae 2021;60(4):63-71.

Key words: rheumatoid arthritis, methotrexate, $H A Q-D I$

\footnotetext{
${ }^{1}$ University of Niš, Faculty of Medicine, Niš, Serbia

${ }^{2}$ Health Center Niš, Niš, Serbia

3University Children's Clinic, Belgrade, Serbia

${ }^{4}$ University of Niš, Faculty of Medicine, Department of

Pharmacy, Niš, Serbia
}

Contact: Nikola Krstić

81 Dr Zoran Djindjić Blvd., 18000 Niš, Serbia

E-mail: nikola.krstic@medfak.ni.ac.rs

\section{Introduction}

Rheumatoid arthritis (RA) is a chronic, systemic inflammatory disease that affects an average of $0.5-1 \%$ of the world's population. The disease is more common in women and can occur at any age, and the highest incidence is between $50-60$ years of age (1). Today, it is known that a large number of factors can influence the development of diseases, both genetic and environmental factors. Expressed in a percentage, the chance of inheriting RA from relatives is from $53 \%$ to $65 \%$, which is 1.6 times higher compared to people who do not have a genetic basis $(1,2)$. Disease progression, chronic inflammation of the joints and consequent joint damage make RA significantly affect functional ability (2). Decreased functional capacity can contribute to: higher unemployment rates, loss of productivity at work, increased health costs and impaired quality of life of patients with arthritis (RA). The Health Assessment Questionnaire (HAQ-DI) (2) is used as the gold standard for assessing the functional status of a patient with RA (2).

Individual approach to each patient, early diagnosis and timely application of anti-inflammatory and immunomodulatory drugs are the 
imperative of modern treatment of RA. There is a wide range of drugs that can be used in the treatment of RA, with the aim of alleviating or absolutely reducing the symptoms of the disease, its progression and preserving the functional status (3). The traditional approach in the treatment of RA is based on the use of conventional synthetic disease-modifying anti-rheumatic drugs (cSDMARDs), glucocorticoids (GC) and non-steroidal anti-inflammatory drugs (NSAIDs) (4). The most commonly used csDMARDs are: methotrexate, sulfasalazine, hydroxychloroquine and leflunomide. Additionally, biological disease-modifying anti-rheumatic drugs (bDMARDs) may be used in the treatment of RA, which include: TNF- $\alpha$ inhibitors, anti-B cell therapy, T-cell costimulatory blockers, IL-6 and IL-1 inhibitors and protein kinase inhibitors (5).

\section{The aim}

The aim of the research was to assess the impact of sociodemographic characteristics, laboratory parameters of interest and therapeutic modalities on the functional ability of patients with RA.

\section{Patients and methods}

The research in the form of a retrospective cross-sectional study was conducted at the Clinic of Rheumatology of the Military Medical Academy in Belgrade. The study included 109 patients diagnosed with rheumatoid arthritis treated during 2019 and 2020. All patients underwent a detailed clinical examination, which included taking anamnestic data, physical examination and standard laboratory diagnostics, which, in addition to classical biochemical analyzes, also included determination of sedimentation rate, reactive $C$ protein (CRP), rheumatoid factor (RF) and anticitrulline antibodies (antiCCP). The functional status of the subjects was assessed based on of the HAQ questionnaire, while the disease activity was assessed based on of the DAS-28 index. The HAQ-DI questionnaire contains questions classified into 8 categories, and they refer to activities related to everyday life (retrieving objects, catching, getting up, getting dressed, feeding, walking, usual daily activities, personal hygiene). By scoring the answers from the questionnaire, the value of the HAQ-DI index is obtained, ranging from 0 (no limit) to 3.0 (complete disability), with values above 1.0 being considered a significant decrease in the patient's functional ability. Subjects were divided into groups according to: gender, age, HAQ values, DAS 28 and therapeutic modalities they applied.

\section{Data processing and statistical analysis}

Standard descriptive and analytical statistical methodology was used in data processing. The following statistical parameters were presented by descriptive statistical analysis: arithmetic mean, standard deviation, min-max range, absolute frequency $(\mathrm{N})$ and structure index (\%). Analytical statistical methodology was used to measure the statistical significance of mutual differences in the average values of certain characteristics of the participants.

The comparison of the average values of the numerical features between the two independent groups of participants was performed by Student's ttest. For categorical variables, the comparison of the frequency of occurrence of individual modalities of attribute features between groups was performed by Pearson $\chi^{2}$ test.

The comparison of the average values of the numerical features between the three independent groups of subjects was performed by the ANOVA test. To measure the correlation of certain features, a correlation analysis (Spearman) was performed. PLUM regression analysis was performed to measure the predictor influence of certain features on the functional ability index.

\section{Statistical analysis}

Statistical analysis was performed using Excel programs from Microsoft Office software package and PASW program, version 18.0. An estimation error level of less than 5\% (0.05) was used as the statistical significance threshold. The results of the statistical analysis are presented in a table.

\section{Results}

The conducted study included 109 subjects, 26 males (23.85\%) and 83 female participants $(76.15 \%)$. Table 1 shows the demographic characteristics of the participants.

The average age was $60.46 \pm 10.97$ years. The average age of men was $60.12 \pm 8.126$ years, and women $60.57 \pm 11$, and statistically did not differ significantly, while a statistically significant difference was observed between the age categories of participants ( $p<0.0001)$.

Clinical characteristics and laboratory parameters of importance are shown in Table 2. Based on the values of the disease activity index, it can be noticed that $48.62 \%$ of the participants had a highly active disease (DAS28 > 5.1). In more than one third of the subjects, the values of the HAQ index were $>1$, which indicates a significant decrease in functional ability. 
Table 1. Demographic characteristics of participants

\begin{tabular}{||c|c||c|c|c||}
\hline \hline Demographic characteristics & $\mathrm{N}(\%)$ & Age & $\mathrm{p}$ \\
\hline \hline \multirow{2}{*}{ Gender } & Men & $26(23.85 \%)$ & $60.12 \pm 8.126$ & \multirow{2}{*}{0.005} \\
\cline { 2 - 4 } & Women & $83(76.15 \%)$ & $60.57 \pm 11.757$ & \\
\hline \multirow{3}{*}{ Age } & $31-50$ years & $16(14.68 \%)$ & $42.06 \pm 6.038$ & \multirow{3}{*}{0.0001} \\
\cline { 2 - 4 } & $51-65$ years & $55(50.46 \%)$ & $58.18 \pm 4.423$ & \\
\cline { 2 - 4 } & $>65$ years & $38(34.86 \%)$ & $71.50 \pm 5.336$ & \\
\hline
\end{tabular}

Table 2. Clinical characteristics and laboratory parameters of importance to the subject

\begin{tabular}{|c|c|c|}
\hline \multicolumn{2}{|c|}{ Clinical characteristics } & N (\%) \\
\hline \multirow{3}{*}{ DAS 28* } & $<2.6$ & $19(17.43 \%)$ \\
\hline & $3.2-5.1$ & $37(33.94 \%)$ \\
\hline & $>5.1$ & $53(48.62 \%)$ \\
\hline \multirow{3}{*}{ HAQ-DI\# } & $0-0.5$ & $16(14.68 \%)$ \\
\hline & $0.55-1$ & $57(52.29 \%)$ \\
\hline & $>1$ & $36(33.03 \%)$ \\
\hline \multirow{5}{*}{ Number of comorbidities } & RA & $20(18.35 \%)$ \\
\hline & $\mathrm{RA}+1$ & $35(32.11 \%)$ \\
\hline & $R A+2$ & $32(29.36 \%)$ \\
\hline & $\mathrm{RA}+3$ & $14(12.84 \%)$ \\
\hline & $R A+4$ & $8(7.34 \%)$ \\
\hline \multicolumn{2}{|c|}{ Laboratory parameters } & N (\%) \\
\hline \multirow{2}{*}{ Sedimentation } & (↔ & $18(16.51 \%)$ \\
\hline & $\uparrow$ & $91(83.47 \%)$ \\
\hline \multirow{2}{*}{ RF } & $\leftrightarrow$ & $44(40.37 \%)$ \\
\hline & $\uparrow$ & $65(59.63 \%)$ \\
\hline \multirow{2}{*}{ Anti-CCP } & $\leftrightarrow$ & $38(34.86 \%)$ \\
\hline & $\uparrow$ & $71(65.14 \%)$ \\
\hline \multirow{2}{*}{ CRP } & $\leftrightarrow$ & $44(40.37 \%)$ \\
\hline & $\uparrow$ & $65(59.63 \%)$ \\
\hline \multirow{2}{*}{ Leukocytes } & $\leftrightarrow$ & $105(96.33 \%)$ \\
\hline & $\uparrow$ & $4(3.67 \%)$ \\
\hline \multirow{3}{*}{ Platelets } & $\leftrightarrow$ & $84(77.06 \%)$ \\
\hline & $\uparrow$ & $8(7.34 \%)$ \\
\hline & $\downarrow$ & $17(15.6 \%)$ \\
\hline
\end{tabular}

$\leftrightarrow$ parameter values are within the reference range;

$\uparrow$ parameter values are above the reference range;

$\downarrow$ parameter values are below the reference range;

* DAS28: 0-2.5: disease remission;

2.6-3.1: low disease activity ;

3.2-5.0: moderate disease activity;

$>$ 5.1: high disease activity;

\#HAQ DI: 0-3.0 indicates a range of functional abilities without limitation to complete disability. 
Table 3. Therapeutic modalities in the study group

\begin{tabular}{|c|c|c|}
\hline \multicolumn{2}{|c|}{ Therapeutic modalities } & N (\%) \\
\hline Therapeutic modality I & GC+MTX* & $30(27.52 \%)$ \\
\hline Therapeutic modality II & GC+other DMARD\# & $27(24.77 \%)$ \\
\hline Therapeutic modality III & GC+multiDMARD $\$$ & $34(31.19 \%)$ \\
\hline Therapeutic modality IV & GC+biological therapy & $18(16.52 \%)$ \\
\hline \multicolumn{2}{|c|}{ Additional RA therapy } & $\mathrm{N}(\%)$ \\
\hline \multirow{2}{*}{ Folic acid } & Does not apply & $37(33.94 \%)$ \\
\hline & Applies & $72(66.06 \%)$ \\
\hline \multirow{2}{*}{ Vitamin D } & Does not apply & $17(15.6 \%)$ \\
\hline & Applies & $92(84.4 \%)$ \\
\hline \multirow{2}{*}{ NSAID } & Does not apply & $62(56.88 \%)$ \\
\hline & Applies & $47(43.12 \%)$ \\
\hline \multirow{2}{*}{ Bisphosphonates } & Does not apply & $95(87.15 \%)$ \\
\hline & Applies & $14(12.85 \%)$ \\
\hline
\end{tabular}

* MTX - methotrexate; \# other disease modifying drug - chloroquine, hydroxychloroquine, sulfasalazine, leflunomide;

$\$$ multiDMARD - more than one disease modifying drug

Table 3 shows the therapeutic modalities used in the treatment of the subjects. The largest number of subjects (31.19\%) received GC and more than one disease modifying drug (MTX/chloroquine, hydroxychloroquine, sulfasalazine, leflunomide), while the smallest number of subjects received biological therapy (etanercept, tofacitinib, rituximab, tocilizumab, golimumab) (16.52\%).

The assessment of the functional ability of the subjects based on the HAQ-DI index, in relation to the applied therapeutic modalities is shown in Table 4.

The analysis of the obtained results showed that the highest number of subjects with a high HAQ-DI index indicating highly impaired functional ability was observed in the group of subjects who used GC in combination with several SCDMARD drugs $(41.2 \%)$. Moderately impaired functional acti- vity was highest in the group of patients treated with GC + MTX while the largest number of regular HAQDI index findings were noted in the group that used biological therapy (44.4\%). HAQ value of the index, significant differences compared to the administered therapeutic modality $(p=0.004)$.

Table 5 shows the correlation of the HAQ-DI index with clinical and laboratory parameters. The Spearman index determined the correlation of HAQ index values in relation to gender, age, present comorbidities and values of sedimentation of erythrocytes, CRP and anti-CCP in serum.

The values of $\mathrm{HAQ}$ as a parameter for the assessment of functional ability, statistically significantly correlated with the values of erythrocyte sedimentation rate $(p<0.05)$, CRP values $(p<0.01)$ and anti-ACCP $(p<0.05)$.

Table 4. Assessment of functional ability in relation to applied therapeutic modalities

\begin{tabular}{|c|c|c|c|c|c|c|}
\hline & $\begin{array}{c}\text { Therapeutic } \\
\text { modality I }\end{array}$ & $\begin{array}{l}\text { Therapeutic } \\
\text { modality II }\end{array}$ & $\begin{array}{l}\text { Therapeutic } \\
\text { modality III }\end{array}$ & $\begin{array}{l}\text { Therapeutic } \\
\text { modality IV }\end{array}$ & $\chi^{2}$ & $p$ \\
\hline HAQ-DI & N (\%) & N (\%) & N (\%) & N (\%) & \multirow{5}{*}{18.914} & \multirow{5}{*}{0.004} \\
\hline Neat finding & $1(3.3 \%)$ & $5(18.5 \%)$ & $2(5.9 \%)$ & $8(44.4 \%)$ & & \\
\hline $\begin{array}{l}\text { Moderately impaired } \\
\text { functional ability }\end{array}$ & $19(63.3 \%)$ & $14(51.9 \%)$ & $18(52.9 \%)$ & $6(33.3 \%)$ & & \\
\hline $\begin{array}{l}\text { Highly impaired } \\
\text { functional ability }\end{array}$ & $10(33.3 \%)$ & $8(29.6 \%)$ & $14(41.2 \%)$ & $4(22.3 \%)$ & & \\
\hline Total & $30(100 \%)$ & $27(100 \%)$ & $34(100 \%)$ & $18(100 \%)$ & & \\
\hline
\end{tabular}

HAQ-DI: orderly finding (0-0.5);

Moderately impaired functional ability $(0.55-1)$;

Highly impaired functional ability $(>1)$;

Therapeutic modality I: GC + MTX;

Therapeutic modality II: GC + other DMARDs (chloroquine, hydroxychloroquine, sulfasalazine, leflunomide);

Therapeutic modality group III: GC + multiDMARD (more than one sCDMARD);

Therapeutic modality IV: GC + bDMARD 
Table 5. Correlation of HAQ index with clinical and laboratory parameters

\begin{tabular}{|c|c|c|c|c|c|c||}
\hline Spearman's correlation & Gender & Age & Comorbidity & AntiCCP & CRP & SE \\
\hline \hline $\mathrm{HAQ}$ & .135 & .084 & .114 & $.210^{*}$ & $.267^{* *}$ & $.225^{*}$ \\
\hline $\mathrm{p}$ & .162 & .385 & .239 & .029 & .005 & .018 \\
\hline $\mathrm{N}$ & 109 & 109 & 109 & 109 & 109 & 109 \\
\hline
\end{tabular}

*p $<0.05 ; * * p<0.01$

PLUM regression was used to assess the predictor effect of individual variables on the degree of functional ability, and the results are shown in Table 6.

The results of the PLUM analysis showed that there was a statistically significantly different increase in the value of HAQ-DI from a normal finding to a moderately impaired functional ability. Up to the highly impaired functional ability, the values of HAQ-
DI in relation to the monitored variables were without statistical significance. The results showed that gender and age were not significant predictors of functional ability, while a lower number of comorbidities was a significant predictor of better functional ability. Therapeutic modalities GC + MTX $(p=0.023)$ and GC + multiDMARD $(p=0.002)$ were statistically significant predictor.

Table 6. Influence of individual variables on the degree of functional ability of RA patients

\begin{tabular}{|c|c|c|c|c|c|c|}
\hline \multicolumn{2}{|c|}{-2 Log Likelihood } & 172.826 & $p=0.005$ & $\begin{array}{c}\text { Cox and } \\
\text { Snell }=0.237\end{array}$ & \multirow{3}{*}{$\begin{array}{c}\text { Nagelkerke }=0.276 \\
\text { Sig. }\end{array}$} & \multirow{3}{*}{ Sig. } \\
\hline \multirow{2}{*}{\multicolumn{2}{|c|}{ Parameter Estimates }} & \multirow[b]{2}{*}{ Estimate } & \multicolumn{2}{|c|}{ 95\% Confidence Interval } & & \\
\hline & & & $\begin{array}{l}\text { Lower } \\
\text { Bound }\end{array}$ & Upper Bound & & \\
\hline \multirow{2}{*}{ Threshold } & [HAQ: moderately impaired] & -2.865 & -4.795 & -.934 & .004 & .004 \\
\hline & [HAQ: highly impaired] & .225 & -1.598 & 2.047 & .809 & .809 \\
\hline \multirow{14}{*}{ Location } & [Gender: male] & .582 & -.352 & 1.516 & .222 & .222 \\
\hline & [Gender: female] & $0^{\mathrm{a}}$ & . & . & . & . \\
\hline & [Age: $31-50$ years] & -.078 & -1.458 & 1.302 & .912 & .912 \\
\hline & [Age: 51-65 years] & .212 & -.674 & 1.098 & .640 & .640 \\
\hline & [Age : > 65 years] & $0^{\mathrm{a}}$ & . & . & . & . \\
\hline & [Comorbidity: without] & -1.984 & -3.883 & -.085 & .041 & .041 \\
\hline & [Comorbidity: 1] & -1.565 & -3.301 & .170 & .077 & .077 \\
\hline & [Comorbidity: 2] & -1.760 & -3.462 & -.057 & .043 & .043 \\
\hline & [Comorbidity: 3] & -.859 & -2.717 & .999 & .365 & .365 \\
\hline & [Comorbidity: 4] & $0^{\mathrm{a}}$ & . & . & . & . \\
\hline & [Therapeutic modality I] & 1.447 & .200 & 2.694 & .023 & .023 \\
\hline & [Therapeutic modality II] & 1.150 & -.110 & 2.410 & .074 & .074 \\
\hline & [Therapeutic modality III] & 1.952 & .693 & 3.211 & .002 & .002 \\
\hline & [Therapeutic modality IV] & $0^{\mathrm{a}}$ & . & . & . & . \\
\hline
\end{tabular}

\section{Discussion}

Rheumatoid arthritis is a disease that leads to irreversible damage to the joints, deformities, consequent incapacity for work and reduced quality of life. Therefore, it is necessary to start treatment immediately after the diagnosis. The study involved 109 participants, 26 men and 83 women, with an average age of $60.46 \pm 10.97$ years (Table 1 ). The ratio of female and male subjects suffering from RA is approximately $3: 1$ and is consistent with the results of other authors (6). Values of laboratory parameters indicating disease activity were elevated in most subjects (RF: 59.63\%; anti-CCP: $65.14 \%$; sedimentation: $83.47 \%$; CRP: $59.63 \%$ ), which is usually associated with aggressive progression illness (7).

The primary goal in the treatment of patients with RA is to establish control of disease activity. In the conducted research, $48.62 \%$ of participants had a highly active disease (DAS28 > 5.1) (Table 2). The results of numerous studies indicate a better 
functional status in the group of patients in whom treatment with the disease by modifying drugs was started immediately after the diagnosis (8-11). Methotrexate is still the "gold standard" for the treatment of RA and is most commonly used as the drug of first choice of all scDMARDs (12-16). In the conducted research, the largest number of subjects $(31.19 \%)$ received a therapeutic modality that included GC and more than one scDMARD (MTX + chloroquine/hydroxychloroquine/sulfasalazine/leflun omide), while the smallest number of subjects was on biological therapy (16.52\%). (Table 3). The combined use of more than one disease-modifying drug is a widely used pharmacotherapeutic strategy. This type of therapy enables the achievement of better therapeutic goals and is not associated with a significant increase in the rate of adverse events compared with monotherapy (17). In their study, Bergstra et al. showed that continuous low disease activity was better achieved with combination therapy when compared with MTX monotherapy (18). Similar results were obtained by other authors whose studies showed that SCDMARDs in monotherapy might be insufficiently effective or that the degree of their effectiveness decreased over time, maintaining the desired therapeutic response in only $5-15 \%$ of patients during five-year follow-up (19, 20). Abud-Mendoza and colleagues in their study concluded that the use of therapeutic modalities with higher doses of methotrexate in combination with prednisone or another combination of SCDMARD reduced the percentage of patients in need of biological therapy, and the distribution of therapeutic modalities in our study is consistent with their results (17). Concomitant use of GC in combination with SCDMARD achieves a higher remission rate, slows down joint destruction and initiates a faster clinical response. In addition to direct therapeutic benefits, clinical studies have suggested that concomitant administration of GK and DMARDs may prolong the effective duration of CSDMARD, as well as reduce the occurrence of cSDMARD-related side effects (21). Current treatment guidelines and recommendations support the initiation of bDMARD therapy in RA patients who do not achieve their therapeutic goals by receiving cSDMARD (22).

The quality of life of patients with RA depends, among other things, on the functional status of the patient, a higher degree of functional incapacity significantly affects everyday life and work ability (23). The results of the research indicate that in more than one third of the participants the values of the HAQ index are higher than 1 , which indicates a significant decrease in functional ability (Table 1). Highly impaired functional ability in patients with RA has been reported in other studies (24).The level of the HAQ-DI index is an important instrument for measuring and monitoring the success/failure of treatment and improving the functional ability of patients with RA (25). The values of the HAQ index differ significantly statistically in relation to the applied therapeutic modality $(p=0.004)$. The analysis of the obtained results shows that the correct finding of the HAQ-ID index in the largest percentage was recorded in the group of subjects who applied biological therapy $(22 \%)$, but it should be emphasized that there was a small number of subjects (16.52 \%) in this group. Given that RA is a progressive disease, it is important to maintain or improve the functional capacity of the RA patient. Accordingly, the results of the conducted research indicate that $63.3 \%$ of participants who used the combination of GC + MTX have moderately impaired functional ability (Table 4). Studies suggest that the application of both sCDMARD and bDMARDS leads to a statistically significant decrease in HAQ-DI index values (26), while Kopciuch et al. in their study show that lower HAQ-DI index values are achieved when bDMARDs are more likely to achieve remission (27).

In the conducted research, there is no statistically significant difference in the values of the $\mathrm{HAQ}$ index in relation to the gender, age and number of comorbidities of the participants. The results of gender influence are incoherent and there are those that confirm that the values of the HAQ index are higher in women than in men (28). When it comes to the influence of age, the results of other studies suggest an inversely proportional effect of age on HAQ-DI values, probably due to the increased number of comorbidities in this group of patients (29). The values of HAQ-DI parameters in the conducted study significantly correlate with the values of erythrocyte sedimentation, CRP and antiCCP values in serum (Table 5). Given that these laboratory parameters are significant predictors of disease course, their elevated values may be associated with reduced functional capacity of patients with RA (30). A study conducted in Turkey on a small number of subjects did not confirm an association between elevated values of anti-CCP and HAQ-DI index, which is contrary to the results obtained in our study (31). On the other hand, the research conducted on the territory of the Southern Serbia confirms the statistically significant influence of elevated values of sedimentation and CRP on HAQ-DI values, which is in line with the results of our research (30).

In order to identify the variables that most significantly correlate with the functional status of the participants, regression analysis was applied. The results indicate that functional ability is impaired in the group of subjects without comorbidity and in those with a lower number of comorbidities, while in patients with a higher number of comorbidities this connection for functional ability was not shown. In order to explain the obtained results, it is necessary to additionally consider the length of presence and severity of associated diseases. In addition, the results of the regression analysis indicate that the combination of GC + MTX $(p=0.023)$ and $G C+$ multiDMARD $(p=0.002)$ can significantly contribute to better functional ability in patients with RA (Table 6 ). The obtained results confirm that the use of MTX, alone or in combination with other drugs, still represents an effective and most often prescribed disease modifying drug in patients with RA.

\section{Conclusion}

Based on the conducted research, we can conclude that methotrexate, alone or in combination with other drugs, can significantly contribute to 
better functional ability and is an effective therapeutic strategy in most patients with rheumatoid arthritis.

\section{Acknowledgments}

The authors would like to thank the Ministry of Education, Science and Technological Development of Republic of Serbia (Grant No: 451-039/2021-14/200113) for financial support.

\section{References}

1. Myasoedova E, Crowson CS, Kremers HM, Therneau TM, Gabriel SE. Is the incidence of rheumatoid arthritis rising?:results from Olmsted County, Minnesota, 1955-2007. Arthritis Rheum 2010;62:1576-82.

[CrossRef] [PubMed]

2. Ji J, Zhang L, Zhang Q, Yin R, Fu T, Li L, Gu Z. Functional disability associated with disease and quality-of-life parameters in Chinese patients with rheumatoid arthritis. Health Qual Life Outcomes 2017; 15(1):89. [CrossRef] [PubMed]

3. National Collaborating Centre for Chronic Conditions. Rheumatoid Arthritis: National Clinical Guideline for Management and Treatment in Adults. London: Royal College of Physicians;2009. [PubMed]

4. Gaujoux-Viala C, Nam J, Ramiro S, Landewé R, Buch $\mathrm{MH}$, Smolen JS, Gossec L. Efficacy of conventional synthetic disease-modifying antirheumatic drugs, glucocorticoids and tofacitinib: a systematic literature review informing the 2013 update of the EULAR recommendations for management of rheumatoid arthritis. Ann Rheum Dis 2014;73(3):510-5. [CrossRef] [PubMed]

5. Smolen JS, Landewé R, Breedveld FC, Buch $M$, Burmester G, Dougados $M$ at al. EULAR recommendations for the management of rheumatoid arthritis with synthetic and biological disease-modifying antirheumatic drugs: 2013 update. Ann Rheum Dis 2014;73(3):492-509. [CrossRef] [PubMed]

6. Intriago M, Maldonado G, Cárdenas J, Ríos C. Clinical Characteristics in Patients with Rheumatoid Arthritis: Differences between Genders. ScientificWorldJournal 2019;2019:8103812. [CrossRef] [PubMed]
7. Šenolt L, Grassi W, Szodoray P. Laboratory biomarkers or imaging in the diagnostics of rheumatoid arthritis? BMC Med 2014;12:49. [CrossRef] [PubMed]

8. Suresh E. Diagnosis of early rheumatoid arthritis: what the non-specialist needs to know. J R Soc Med 2004;97(9):421-24. [CrossRef] [PubMed]

9. Pincus T, Ferraccioli G, Sokka T, Larsen A, Rau R, Kushner I et al. Evidence from clinical trials and longterm observational studies that disease-modifying antirheumatic drugs slow radiographic progression in rheumatoid arthritis: updating a 1983 review. Rheumatology 2002;41:1346-56. [CrossRef] [PubMed]

10. Kahlenberg JM, Fox DA. Advances in the Medical Treatment of Rheumatoid Arthritis. Hand Clin 2011; 27(1):11-20. [CrossRef] [PubMed]

11. Verstappen SMM, Jacobs JWG, Bijlsma JWJ, Heurkens AHM, Van BoomaFrankfort C, Ter Borg EJ et al. Fiveyear followup of rheumatoid arthritis patients after early treatment with disease-modifying antirheumatic drugs versus treatment according to the pyramid approach in the first year. Arthritis and Rheumatism 2003;48(7):1797-1807. [CrossRef] [PubMed]

12. Albrecht K, Zink A. Poor prognostic factors guiding treatment decisions in rheumatoid arthritis patients: a review of data from randomized clinical trials and cohort studies. Arthritis Research \& Therapy 2017; 19:68. [CrossRef] [PubMed]

13. Shinde CG, Venkatesh MP, Kumar TM, Shivakumar HG. Methotrexate: a gold standard for treatment of rheumatoid arthritis. J Pain Palliat Care Pharmacother 2014;28(4):351-8. [CrossRef] [PubMed] 
14. Favalli EG, Biggioggero M, Meroni PL. Methotrexate for the treatment of rheumatoid arthritis in the biologic era: still an "anchor" drug? Autoimmun Rev 2014; 13(11):1102-1108. [CrossRef] [PubMed]

15. Swierkot J, Szechiński J. Methotrexate in rheumatoid arthritis. Pharmacol Rep 2006;58(4):473-492.158.

16. Wisłowska M, Jakubicz D. Preliminary evaluation in rheumatoid arthritis activity in patients treated with TNF-alpha blocker plus methotrexate versus methotrexate or leflunomide alone. Rheumatol Int 2007; 27(7):641-7. [CrossRef] [PubMed]

17. Abud-Mendoza C, Martínez-Martínez MU. Triple therapy with non-biologic DMARDs for rheumatoid arthritis or biologic therapy. Is it the same? Reumatol Clin 2014;10(5):345-6. [CrossRef] [PubMed]

18. Bergstra S, Landewé R, Huizinga T, Allaart C. Rheumatoid arthritis patients with continued low disease activity have similar outcomes over 10 years, regardless of initial therapy. Rheumatology (Oxford). 2017;56(10):1721-8. [CrossRef] [PubMed]

19. Suresh E, Lambert CM. Combination treatment strategies in early rheumatoid arthritis. Ann Rheum Dis 2005;64(9):1252-6. [CrossRef] [PubMed]

20. Burmester GR, Pope JE. Novel treatment strategies in rheumatoid arthritis. Lancet. 2017;10;389(10086): 2338-48. [CrossRef] [PubMed]

21. Shams S, Martinez JM, Dawson JRD, Flores J, Gabriel M, Garcia G, et al. Therapeutic Landscape of Rheumatoid Arthritis: Current State and Future Directions. Front Pharmacol 2021;12:680043. [CrossRef] [PubMed]

22. Smolen JS, Landewe R, Bijlsma J, Burmester GR, Dougados $M$, Kerschbaumer A et al. EULAR recommendations for the management of rheumatoid arthritis with synthetic and biological disease-modifying antirheumatic drugs: 2016 update. Ann Rheum Dis 2017;76:960-77. [CrossRef] [PubMed]

23. Michaud K, Wallenstein G, Wolfe F. Treatment and nontreatment predictors of health assessment questionnaire disability progression in rheumatoid arthritis: a longitudinal study of 18,485 patients. Arthritis Care Res (Hoboken) 2011;63(3):366-72. [CrossRef] [PubMed]
24. Karpouzas GA, Draper T, Moran R, Hernandez E, Nicassio $\mathrm{P}$, Weisman $\mathrm{MH}$, Ormseth $\mathrm{S}$. Trends in Functional Disability and Determinants of Clinically Meaningful Change Over Time in Hispanic Patients With Rheumatoid Arthritis in the US. Arthritis Care Res (Hoboken) 2017;69(2):294-8. [CrossRef] [PubMed]

25. Research USDoHaHSFCfDEa. Guidance for industry: patient-reported outcome measures: use in medical product development to support labeling claims: draft guidance. Health Qual Life Outcomes 2006;4:79. [CrossRef] [PubMed]

26. Pollard L, Choy EH, Scott DL. The consequences of rheumatoid arthritis: quality of life measures in the individual patient. Clin Exp Rheumatol 2005;23(5 Suppl 39):S43-52. [PubMed]

27. Kopciuch D, Paczkowska A, Leszczynsk P, Michalak M, Nowakowskai E. Effect of therapy with anti-tnf a drugs and dmard on disease activity and health related quality of life among women with rheumatoid arthritis. Acta Pol Pharm 2016;73(2):547-54. [PubMed]

28. Ahlmén $M$, Svensson $B$, Albertsson $K$, Forslind $K$, Hafström I, BARFOT Study Group. Influence of gender on assessments of disease activity and function in early rheumatoid arthritis in relation to radiographic joint damage. Ann Rheum Dis 2010;69(1):230-3. [CrossRef] [PubMed]

29. Martin WJ, Shim M, Paulus HE, Chaudhari S, Feng J, Elashoff $D$ et al. Older age at rheumatoid arthritis onset and comorbidities correlate with less Health Assessment Questionnaire-Disability Index and Clinical Disease Activity Index response to etanercept in the RADIUS 2 registry. J Clin Rheumatol 2014;20(6): 301-5. [CrossRef] [PubMed]

30. Jovanović J, Stojanović $M$, Jovanović $V$, Dimić $A$, Božilov S, Stamenković B, Milenković S. Influence of disease activity on functional capacity in patients with rheumatoid arthritis. Vojnosanit Pregl 2015;72(1):215. [CrossRef] [PubMed]

31. Önder B, Kurtaran A, Kimyon S, Selçuk B, Akyüz M. Association of anti-CCP positivity with serum ferritin and DAS-28. Rheumatol Int 2009;30(2):223-7. [CrossRef] [PubMed] 


\title{
UTICAJ TERAPIJSKIH MODALITETA NA FUNKCIONALNU SPOSOBNOST BOLESNIKA SA REUMATOIDNIM ARTRITISOM
}

\author{
Nikola Krstić ${ }^{1}$, Ivana Kostić ${ }^{2}$, Ana Petronijevićc ${ }^{3}$ Ivana Damnjanović ${ }^{4}$
}

${ }^{1}$ Univerzitet u Nišu, Medicinski fakultet, Niš, Srbija

${ }^{2}$ Dom zdravlja Niš, Niš, Srbija

${ }^{3}$ Univerzitetska dečja klinika, Beograd, Srbija

${ }^{4}$ Univerzitet u Nišu, Medicinski fakultet, Departman za farmaciju, Niš, Srbija

Kontakt: Nikola Krstić

Bulevar dr Zorana Đinđića 81, 18000 Niš, Srbija

E-mail: nikola.krstic@medfak.ni.ac.rs

Reumatoidni artritis (RA) je hronična, sistemska, inflamatorna bolest. Progresivnost bolesti i oštećenje zglobova izazvano RA može značajno uticati na sposobnost funkcionisanja. Zlatni standard za procenu funkcionalnog statusa u RA je $H A Q$ upitnik.

Cilj rada bio je da se proceni uticaj sociodemografskih karakteristika, laboratorijskih parametara od interesa i terapijskih modaliteta na funkcionalnu sposobnost bolesnika sa RA.

Retrospektivna studija preseka uključivala je 109 bolesnika, 29 muškaraca i 83 žene, sa dijagnozom RA. Prikupljeni su podaci o demografskim i kliničkim karakteristikama bolesnika, laboratorijskim nalazima i primenjenim terapijskim modalitetima. Za statističku analizu korišćeni su Microsoft Office Excel i PASW. Nivo greške procene manji od 5\% $(0,05)$ korišćen je kao prag statističke značajnosti.

Rezultati studije ukazuju da više od trećine učesnika ima $H A Q-D I$ indeks veći od 1 , što ukazuje na značajno smanjenje funkcionalne sposobnosti. Najveći broj ispitanika sa visokim $H A Q-D I$ indeksom $(41,2 \%)$ zabeležen je u grupi ispitanika koji su koristili glukokortikoide u kombinaciji sa nekoliko sintetičkih lekova koji modifikuju bolest (GK + multiDMARD). Vrednosti $H A Q-D I$ indeksa statistički se značajno razlikuju u odnosu na primenjene terapijske modalitete $(p=0,004)$. HAQ-DI indeks značajno je korelirao sa vrednostima brzine sedimentacije $(p<0,05)$, CRP $(p<0,01)$ i anti-CCP $(p<0,05)$. PLUM regresiona analiza pokazala je da je funkcionalna sposobnost oštećena u grupama ispitanika bez komorbiditeta $i$ sa manjim brojem komorbiditeta. Pored toga, rezultati regresione analize ukazuju na to da terapijski modaliteti GK + metotreksat $(p=0,023)$ i GK + multiDMARD $(p=0,002)$ mogu značajno doprineti boljoj funkcionalnoj sposobnosti bolesnika sa RA.

Metotreksat, sam ili u kombinaciji sa drugim lekovima, može značajno doprineti boljoj funkcionalnoj sposobnosti i efikasan je u lečenju većine bolesnika sa RA.

$$
\text { Acta Medica Medianae 2021;60(4):63-71. }
$$

KIjučne reči: reumatoidni artritis, metotreksat, $H A Q-D I$ 